\title{
Article \\ Preparation and Characterization of Electrospun Polysaccharide FucoPol-Based Nanofiber Systems
}

\author{
Yuliana Vázquez-González ${ }^{1,2}$, Cristina Prieto ${ }^{1, * \mathbb{D}}$, Milan Stojanovic ${ }^{1,+}{ }^{\text {, }}$, Cristiana A. V. Torres ${ }^{3,4}$, \\ Filomena Freitas ${ }^{3,4}\left(\mathbb{D}\right.$, Juan Arturo Ragazzo-Sánchez ${ }^{2} \mathbb{D}$, Montserrat Calderón-Santoyo ${ }^{2, *(D)}$ \\ and Jose M. Lagaron $1, *(D)$
}

\section{check for}

updates

Citation: Vázquez-González, Y.;

Prieto, C.; Stojanovic, M.; Torres,

C.A.V.; Freitas, F.; Ragazzo-Sánchez,

J.A.; Calderón-Santoyo, M.; Lagaron,

J.M. Preparation and

Characterization of Electrospun

Polysaccharide FucoPol-Based

Nanofiber Systems. Nanomaterials

2022, 12, 498. https://doi.org/

$10.3390 /$ nano12030498

Academic Editor: Takuya Kitaoka

Received: 30 December 2021

Accepted: 29 January 2022

Published: 31 January 2022

Publisher's Note: MDPI stays neutral with regard to jurisdictional claims in published maps and institutional affiliations.

Copyright: () 2022 by the authors Licensee MDPI, Basel, Switzerland. This article is an open access article distributed under the terms and conditions of the Creative Commons Attribution (CC BY) license (https:// creativecommons.org/licenses/by/ $4.0 /)$.
1 Novel Materials and Nanotechnology Group, Institute of Agrochemistry and Food Technology (IATA), Spanish Council for Scientific Research (CSIC), Calle Catedrático Agustín Escardino Benlloch 7, 46980 Paterna, Spain; yuliana.vg04@gmail.com (Y.V.-G.); milan87stojanovic@gmail.com (M.S.)

2 Laboratorio Integral de Investigación de Alimentos, Tecnológico Nacional de México-Instituto Tecnológico de Tepic, Av. Tecnológico \#2595, Tepic 63175, Mexico; arturoragazzo@hotmail.com

3 UCIBIO-Applied Molecular Biosciences Unit, Department of Chemistry, School of Science and Technology, NOVA University Lisbon, 2819-516 Caparica, Portugal; c.torres@fct.unl.pt (C.A.V.T.); a4406@fct.unl.pt (F.F.)

4 Associate Laboratory i4HB-Institute for Health and Bioeconomy, School of Science and Technology, NOVA University Lisbon, 2819-516 Caparica, Portugal

* Correspondence: cprieto@iata.csic.es (C.P.); montserratcalder@gmail.com (M.C.-S.); lagaron@iata.csic.es (J.M.L.); Tel.: +34-963-900-022 (C.P. \& J.M.L.)

+ On leave from the Department of Food Technology and Biochemistry, Faculty of Agriculture, University of Belgrade, 11000 Belgrade, Serbia.

\begin{abstract}
The electrospinnability of FucoPol, a bacterial exopolysaccharide, is presented for the first time, evaluated alone and in combination with other polymers, such as polyethylene oxide (PEO) and pullulan. The obtained fibers were characterized in terms of their morphological, structural and thermal properties. Pure FucoPol fibers could not be obtained due to FucoPol's low water solubility and a lack of molecular entanglements. Nanofibers were obtained via blending with PEO and pullulan. FucoPol:PEO (1:3 w/w) showed fibers with well-defined cylindrical structure, since the higher molecular weight of PEO helps the continuity of the erupted jet towards the collector, forming stable fibers. WAXS, DSC and TGA showed that FucoPol is an amorphous biopolymer, stable until $220^{\circ} \mathrm{C}$, whereas FucoPol-PEO fibers were stable until $140^{\circ} \mathrm{C}$, and FucoPol:pullulan fibers were stable until $130^{\circ} \mathrm{C}$. Interestingly, blended components influenced one another in intermolecular order, since new peaks associated to intermolecular hierarchical assemblies were seen by WAXS. These results make FucoPol-based systems viable candidates for production of nanofibers for packaging, agriculture, biomedicine, pharmacy and cosmetic applications.
\end{abstract}

Keywords: FucoPol; exopolysaccharide; electrospinning process; nanofibers; characterization

\section{Introduction}

Exopolysaccharides (EPS) are water-soluble, non-toxic, high-molecular-weight polymeric carbohydrate structures composed monosaccharide units joined together by glycosidic bonds [1]. EPS can be homopolysaccharides when composed of a single type of monosaccharide, for example, pullulan; or heteropolysaccharides if they are composed of two or more sugars with different ratios, such as FucoPol [2].

FucoPol is an EPS produced by Enterobacter A47, using glycerol as the sole carbon source [3]. It is a high-molecular-weight $\left(4.19 \times 10^{6}-5.80 \times 10^{6}\right)$ heteropolysaccharide composed of sugar residues [fucose (32-36 mol \%), galactose (25-26 mol \%), glucose (28-34 $\mathrm{mol} \%$ ) and glucuronic acid (9-10 $\mathrm{mol} \%)$ ], as well as acyl groups [pyruvate (13-14 wt.\%), succinate (3 wt.\%) and acetate (3-5 wt.\%)] [4]. It has an anionic character, with interesting functional properties, including emulsion, film-forming [5], thickening, and flocculating capacity; biological activity and adhesive and photoprotective properties $[6,7]$. 
All these properties make FucoPol an interesting candidate for food packaging, agriculture, biomedicine, pharmacy, food and cosmetics applications. Hence, up to now, several research works have studied the potential of FucoPol. For instance, Lourenço et al. evaluated the ability of FucoPol to be used as encapsulation matrix of some bioactive compounds by spray drying [8]. Concordio-Reis et al. [9] studied the stabilization properties of FucoPol in the production of a FucoPol/AgNP biocomposite for wound-healing applications. Additionally, Ferreira et al. [10-13] studied the development of FucoPol films by casting. These films have shown to be transparent and hydrophilic, with high permeability to water vapor, but presented good barrier properties against oxygen and carbon dioxide.

Electrohydrodynamic processes are commonly used for the formation of micro, submicro and nanostructures. This technology utilizes electrical forces to produce ultrathin fiber-based morphologies from different polymers (natural and synthetic) with diameters ranging from $2 \mathrm{~nm}$ to several micrometers. In the electrospinning process, a polymer solution in a capillary tube is subjected to an electric field $[14,15]$. When the applied electric field reaches a critical value, the repulsive electrical forces overcome the surface tension forces. Eventually, a charged jet of the solution is ejected from the tip of the Taylor cone, and an unstable and rapid whipping jet occurs in the space between the capillary tip and the collector, which leads to evaporation of the solvent at room temperature $[14,16,17]$. The produced micro and nanostructures may offer many functional advantages, such as superior mechanical properties, flexibility, large surface-to-mass ratio, tailored morphology, tunable porosity and the capability of encapsulation and subsequent release of active and bioactive compounds [18-23]. In addition, mechanical properties, thermal stability, electrical conductivity, photocatalytic activity and bioactivity can be tuned by controlling the diameter [23]. These unique characteristics make electrospun micro and nanostructures attractive for novel applications in drug delivery, agriculture, food packaging, biomedical engineering, air filtration, energy production and storage, environmental protection and improvement, photonic and electronic devices $[23,24]$.

To the best of our knowledge, the formation of non-woven FucoPol-based structures by electrospinning has not been reported yet. For this reason, the aim of this research was to study, for the first time, the possibility of producing FucoPol fibers via electrospinning, since the combination of characteristics of the electrospun fibers together with the interesting functional properties of FucoPol could be of great interest for potential applications in food packaging, agriculture, biomedicine, pharmaceutics, food and cosmetics, among others. The electrospinnability of FucoPol was characterized alone and in combination with wellknown electrospinnable polymers, such as polyethylene oxide (PEO) and pullulan. The obtained fibers were characterized in terms of their morphological, structural and thermal properties.

\section{Materials and Methods}

\subsection{Materials}

FucoPol (Mw $\left.\sim 4.4 \times 10^{6} \mathrm{Da}\right)$ was provided by the Biochemical Engineering Group of Nova School of Sciences and Technology (Caparica, Portugal). FucoPol was produced and purified using the same procedures described by Ferreira et al. and Alves et al. [10,25]. The obtained FucoPol was characterized in terms of its chemical composition, as described by Alves et al. [25]. This heteropolysaccharide was composed of neutral sugars: fucose, galactose and glucose. The relative proportion of sugar monomers was $38 \%$ glucose, $25 \%$ fucose and $32 \%$ galactose. Regarding the content of acyl groups, it reached $12 \%$ of the polymer mass, with acetyl, pyruvil and succinyl groups in greatest abundance. The obtained sample also contained non-sugar contaminants, such as proteins and inorganic residues. The protein content was $12 \mathrm{wt} . \%$, and the total content of inorganic residues, determined by pyrolysis at $550{ }^{\circ} \mathrm{C}$, was $32.5 \%$. Regarding the purified polymer's average molecular weight and polydispersity index, they were determined by size-exclusion chromatography combined with multiple-angle laser light scattering (SEC-MALLS), as described in the work 
of Hilliou et al. [26]. The average molecular weight was around $1.1 \times 10^{7} \pm 2.3 \times 10^{5}$ $\mathrm{g} / \mathrm{mol}$, with an average polydispersity index of $1.85 \pm 0.14$.

Pullulan ( $\mathrm{Mw} \sim 2 \times 10^{5} \mathrm{Da}$ ) was purchased from Hayashibara Co., Ltd. (Tokyo, Japan), and polyethylene oxide (PEO) (Mw 100,000 Da), 2,2,2-trifluoroethanol and Span 20 were purchased from Sigma Aldrich (St. Louis, MO, USA). Absolute ethanol (EPR. Ph.Eur.) was obtained from Labkem (Vilassar de Dalt, Spain). Distillated water was used throughout the study.

\subsection{Preparation and Characterization of Polymeric Solutions}

Solutions of FucoPol were prepared with a concentration of $0.015 \mathrm{~g} / \mathrm{mL}$ in distilled water, as well as in a mixture of ethanol:water $(30: 70 \mathrm{v} / \mathrm{v})$ at the same concentration. Solubility tests were conducted in absolute ethanol and 2,2,2-trifluoroethanol; however, FucoPol was not soluble in these solvents (results not shown), and consequently, these formulations were not tested in electrospinning. After that, in order to improve the formation of fibers, blends with two well-known electrospinnable polymers were also studied, i.e., PEO and pullulan. Different ratios were studied to find the minimum amount of polymer of high molecular weight required to generate the molecular entanglements necessary to obtain the sought fibers. In order to reduce surface tension and to make the process more stable to obtain suitable fibers, ethanol-water solution $(30: 70 v / v)$ was used for the solutions with PEO and pullulan. The concentration of FucoPol in the solutions was maintained at $0.015 \mathrm{~g} / \mathrm{mL}$, and different ratios were explored, as shown in Table 1 . Span 20 was used as a surfactant at a concentration of $3 \%(w / w)$. All formulations were proper solutions without solid residues.

Table 1. Polymer ratio employed for the preparation of the nanofibers via electrospinning. All solutions contained 3\% of Span 20 as a surfactant.

\begin{tabular}{cc}
\hline $\begin{array}{c}\text { FucoPol/PEO } \\
(w / w)\end{array}$ & $\begin{array}{c}\text { FucoPol/Pullulan } \\
(w / w)\end{array}$ \\
\hline $3: 1$ & $3: 1$ \\
$2: 1$ & $2: 1$ \\
$1: 0$ & $1: 0$ \\
$0: 1$ & $0: 1$ \\
$1: 2$ & $1: 2$ \\
$1: 3$ & $1: 3$ \\
\hline
\end{tabular}

Characterization of the solutions with the best electrospinning processing was made in terms of viscosity, conductivity and surface tension. Viscosity was measured using a Visco Basic Plus L rotational viscometer (Fungilab S.A., Sant Feliu de Llobregat, Spain). Surface tension was determined in an Easy Dyne K20 tensiometer (Krüss GmbH, Hamburg, Germany) following the Wilhelmy plate method. Conductivity was measured using a conductivity meter (HI-4521 portable meter, Hanna Instruments, Gothenburg, Sweden). Measurements were taken in triplicate at room temperature.

\subsection{Electrospinning Process}

The electrospinning process was performed in a high-throughput Fluidnatek ${ }^{\circledR}$ LE-500 from Bioinicia S.L. (Valencia, Spain). The solutions of FucoPol in water and FucoPol in ethanol:water $(30: 70 \mathrm{v} / \mathrm{v})$ were processed using different processing conditions in order to obtain fibers. The studied range of operation parameters was: flow rate between 250 and $500 \mu \mathrm{L} / \mathrm{h}$, work distance between 15 and $30 \mathrm{~cm}$, and voltage between 16 and $23 \mathrm{kV}$. Temperature and relative humidity $(\mathrm{RH})$ were controlled at $35^{\circ} \mathrm{C}$ and $28 \%$, respectively.

\subsection{Characterization of Electrospinning Fibers}

2.4.1. Scanning Electron Microscopy (SEM)

The morphology of the obtained fibers was determined using a Hitachi-S-4800 FE-SEM scanning electron microscope (Hitachi High-Technologies Corporation, Tokyo, Japan) with 
an electron-beam acceleration of $10 \mathrm{kV}$. Approximately $1.5 \mathrm{mg}$ of sample was placed using double-sided tape on the sample holder and coated with a gold-palladium layer. Fiber sizes were analyzed using Image J Launcher v1.41 software (National Institutes of Health, Bethesda, MD, USA). The presented data are based on measurements from a minimum of 100 fibers.

\subsubsection{Attenuated Total Reflectance Fourier Transform Infrared Spectroscopy (ATR-FTIR)}

To evaluate possible interactions between the different polymers that integrated the fibers, ATR-FTIR (Bruker FTIR Tensor 37 equipment, Rheinstetten, Germany) was used. The samples were placed on top of the diamond crystal, and appropriate contact was assured by using the Golden Gate low-temperature ATR sampling accessory (Specac Ltd., Orpington, UK). All spectra were obtained within the wavenumber range of $4000-600 \mathrm{~cm}^{-1}$ by averaging 10 scans at $4 \mathrm{~cm}^{-1}$ resolution. Analysis of spectral data was carried out using Origin Pro, Version 2019 (OriginLab Corporation, Northampon, MA, USA).

\subsubsection{Differential Scanning Calorimetry (DSC)}

Thermal transitions were studied by differential scanning calorimetry (DSC) on a DSC-8000 analyzer equipped with the Intracooler 2 cooling accessory from PerkinElmer, Inc. (Waltham, MA, USA). Three sweeps were done: a first heating step from $30^{\circ} \mathrm{C}$ to $250{ }^{\circ} \mathrm{C}$, followed by a cooling step from 250 to $-25^{\circ} \mathrm{C}$ and completed by a second heating from -25 to $300{ }^{\circ} \mathrm{C}$. The heating and cooling rates were both set at $10^{\circ} \mathrm{C} / \mathrm{min}$, and the sample weight was around $3 \mathrm{mg}$. An empty aluminum pan was used as reference, whereas calibration was performed using an indium sample. The values of melting point (Tm) and enthalpy of melting $(\Delta \mathrm{Hm})$ were obtained from the heating scan, while the crystallization temperature from melt $(\mathrm{Tc})$ and enthalpy of crystallization $(\Delta \mathrm{Hc})$ was determined from the cooling scan.

\subsubsection{Wide-Angle X-ray Scattering (WAXS)}

The crystallinity of the fibers and pure polymers were assessed by WAXS using a Bruker AXS D4 Endeavor diffractometer (Bruker, Ettlingen, Germany), similarly to a

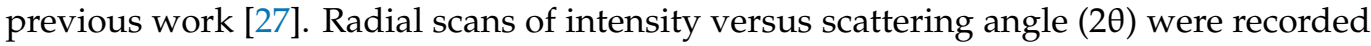
at room temperature in the range of 2 to $40^{\circ}(2 \theta)$ (step size $=0.02^{\circ}(2 \theta)$, scanning rate $=$ $4 \mathrm{~s} / \mathrm{step})$ with filtered $\mathrm{CuK} \alpha$ radiation $(\lambda=1.54 \AA)$, an operating voltage of $40 \mathrm{kV}$ and a filament current of $40 \mathrm{~mA}$.

\subsubsection{Thermogravimetric Analysis (TGA)}

Thermogravimetric analysis of all polymers and fibers was done in triplicate using a 550-TA thermogravimetric analyzer (New Castle, DE, USA). The analyses were carried out under the following conditions: $1-5 \mathrm{mg}$ of sample, heating from $25^{\circ} \mathrm{C}$ to $600{ }^{\circ} \mathrm{C}$, at a heating rate $10{ }^{\circ} \mathrm{C} / \mathrm{min}$ under nitrogen flow $(50 \mathrm{~mL} / \mathrm{min})$.

\subsection{Statistical Analysis}

Data were analyzed by ANOVA with a $p$-value $<0.05$. Fisher test was used for the comparison of means. STATISTICA 10 software (Statsoft Inc., Tulsa, OK, USA) was used for statistical analysis.

\section{Results and Discussion}

The aim of this work was to assess the electrospinnability of FucoPol and its blends with PEO and pullulan.

\subsection{Physicochemical Characterization of Solutions}

A fundamental step before electrospinning is to physicochemically characterize the solutions. These parameters govern the behavior of the solution throughout the process. Solutions of FucoPol in different solvents and FucoPol with complementary polymers were 
characterized in terms of viscosity, surface tension and conductivity. Table 2 shows the characterization of the solutions of pure FucoPol, as well as the solutions of FucoPol:pullulan $(2: 1$ ratio, $w / w)$ and FucoPol:PEO (1:3 ratio, $w / w)$. Viscosity is an important parameter in the electrospinning process in terms of good fiber formation, since below a critical value, the polymeric fibers break up the jet and form droplets on their way to the collector. However, a high viscosity makes it difficult to pass through the syringe needle of the equipment and stabilize the electrospinning process [28,29]. FucoPol water solutions showed a viscosity of $24.8 \pm 0.3 \mathrm{~Pa} \cdot \mathrm{s}$. This value is low in comparison with values reported in the literature. Araújo et al. [6], reported a value of $43 \mathrm{~Pa} \cdot \mathrm{s}$, but the difference could be due to the EPS extraction process, since some authors decrease the viscosity of the bacterial broth, either through dilutions with distilled water or by adjusting $\mathrm{pH}$ with $\mathrm{H}_{2} \mathrm{SO}_{4}$ to increase the production of EPS $[9,30]$.

Table 2. Physicochemical properties of different dissolutions: FucoPol in water, FucoPol with pullulan (2:1 ratio, $w / w)$ and FucoPol with PEO (1:3 ratio, $w / w)$ in ethanol:water (30:70 v/v).

\begin{tabular}{cccc}
\hline Sample & $\begin{array}{c}\text { Viscosity } \\
(\mathbf{P a} \cdot \mathbf{s})\end{array}$ & $\begin{array}{c}\text { Surface tension } \\
(\mathbf{m N / m})\end{array}$ & $\begin{array}{c}\text { Conductivity } \\
(\mathbf{m S} / \mathbf{c m})\end{array}$ \\
\hline FucoPol in water & $24.8 \pm 0.3^{\mathrm{c}}$ & $64.20 \pm 0.40^{\mathrm{a}}$ & $1.55 \pm 0.00^{\mathrm{a}}$ \\
FucoPol + Pullulan, ratio 2:1 & $38.9 \pm 0.1^{\mathrm{b}}$ & $41.00 \pm 0.40^{\mathrm{c}}$ & $0.53 \pm 0.00^{\mathrm{b}}$ \\
FucoPol + PEO, ratio 1:3 & $98.1 \pm 0.5^{\mathrm{a}}$ & $43.90 \pm 0.10^{\mathrm{b}}$ & $0.50 \pm 0.01^{\mathrm{c}}$ \\
\hline
\end{tabular}

Each column represents the mean \pm standard deviation of three independent replicas. Different letters (a-c) in each column indicate a significant difference $(p<0.05) .{ }^{*}$ All samples were Newtonian fluids.

The increased viscosity of FucoPol:pullulan solution, $38.9 \pm 0.1 \mathrm{~Pa} \cdot \mathrm{s}$, is attributed to the addition of pullulan and the higher percentage of solids in the final solution $(2.25 \%$ in comparison with $1.50 \%$ for FucoPol). In addition, ethanol increased the viscosity of the solutions of FucoPol with pullulan and FucoPol with PEO in comparison with the same solutions prepared with water (results not shown). The solution of FucoPol with PEO showed a viscosity of $98.1 \pm 0.5 \mathrm{~Pa} \cdot \mathrm{s}$. This value was statistically significant in comparison with the previous solutions. This behavior was mainly attributed to the high molecular weight of PEO.

FucoPol had a surface tension of $64.20 \pm 0.40 \mathrm{mN} / \mathrm{m}$. This value was high and does not ensure stability during the electrohydrodynamic process [31]. A decrease in surface tension occurred when a mixture of water and ethanol (70:30, $v / v)$ was used instead of pure water, as shown in Table 2. In other words, the solutions with pullulan and PEO showed values of $41.00 \pm 0.40 \mathrm{mN} / \mathrm{m}$ and $43.90 \pm 0.10 \mathrm{mN} / \mathrm{m}$, respectively, since the surface tension of each solution is dependent on the polymer and the solvent used and on the presence of Span 20 [15].

In the same way, conductivity decreased when ethanol was added to the solutions with pullulan and PEO. Highly conductive solutions, such as FucoPol, are extremely unstable in the presence of strong electric fields, and led to a high bending instability [32].

\subsection{Production of Nanofibers by Electrospinning}

In spite of using different processing conditions, it was not possible to obtain fibers using pure FucoPol in water (Figure 1a) and ethanol:water (30:70 v/v) (Figure 1b) due to the low solubility of the biopolymer in water [10-13], which produces a low solid concentration in the solution, as well as the lack of polymer chain entanglements [33]. For this reason, different ratios with other polymers and process conditions were evaluated. Figure 2 shows the micrographs obtained by SEM of the different solutions of FucoPol:pullulan. Figure 2a-e shows fibers with cylindrical structure but with the presence of some beads, which are more visible at a ratio of 1:2 (Figure $2 \mathrm{~d}$ ). Sinuous fibers occur by warping the jet due to the impact with the collector plate, which is also closely related to the viscosity of the solution and the rigidity of the jets [34]. Bead formation occurs mainly due to the high surface tension and viscoelastic properties of the solution, as well as the operating parameters used [19], affecting the homogeneity of the fibers. 

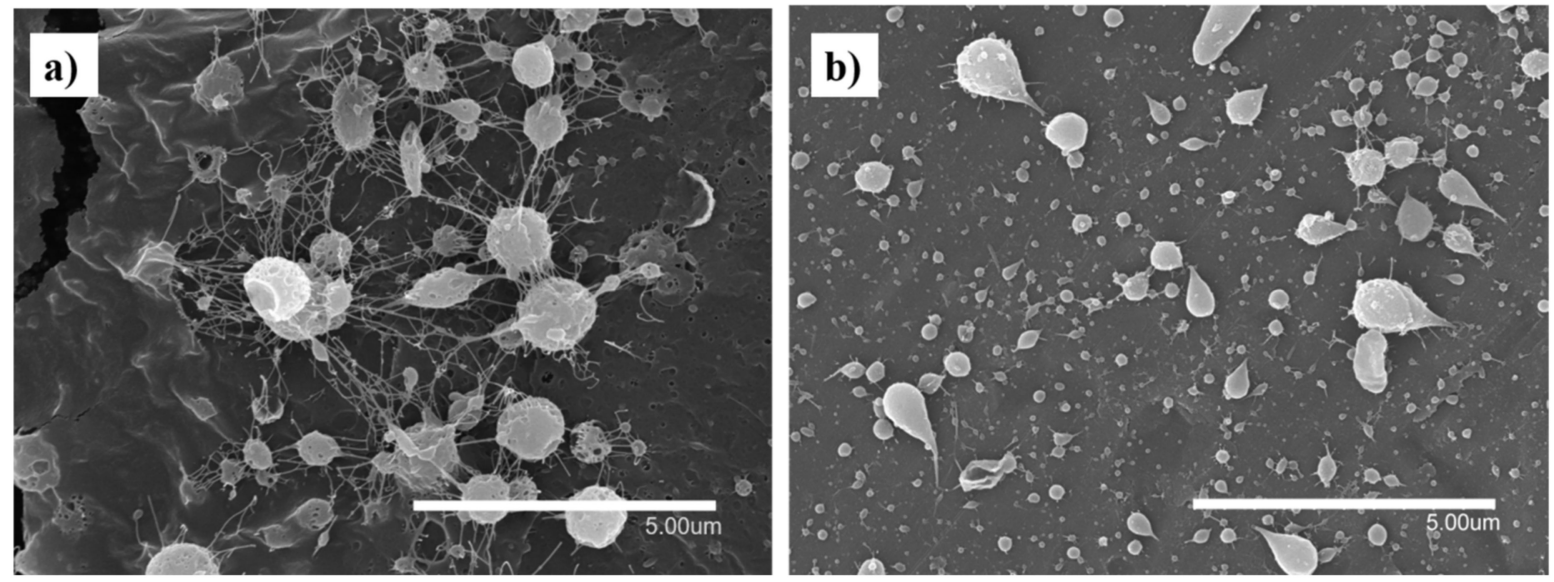

Figure 1. Fibers and capsules of FucoPol in water. (a) (optimal conditions: $500 \mu \mathrm{L} / \mathrm{h}, 25 \mathrm{~cm}$ between collector and needle and $21 \mathrm{kV}$ ) and ethanol:water, (b) (optimal conditions: $500 \mu \mathrm{L} / \mathrm{h}, 15 \mathrm{~cm}$ between collector and needle and $15.5 \mathrm{kV}$ in the injector and $-3.6 \mathrm{kV}$ in the collector).
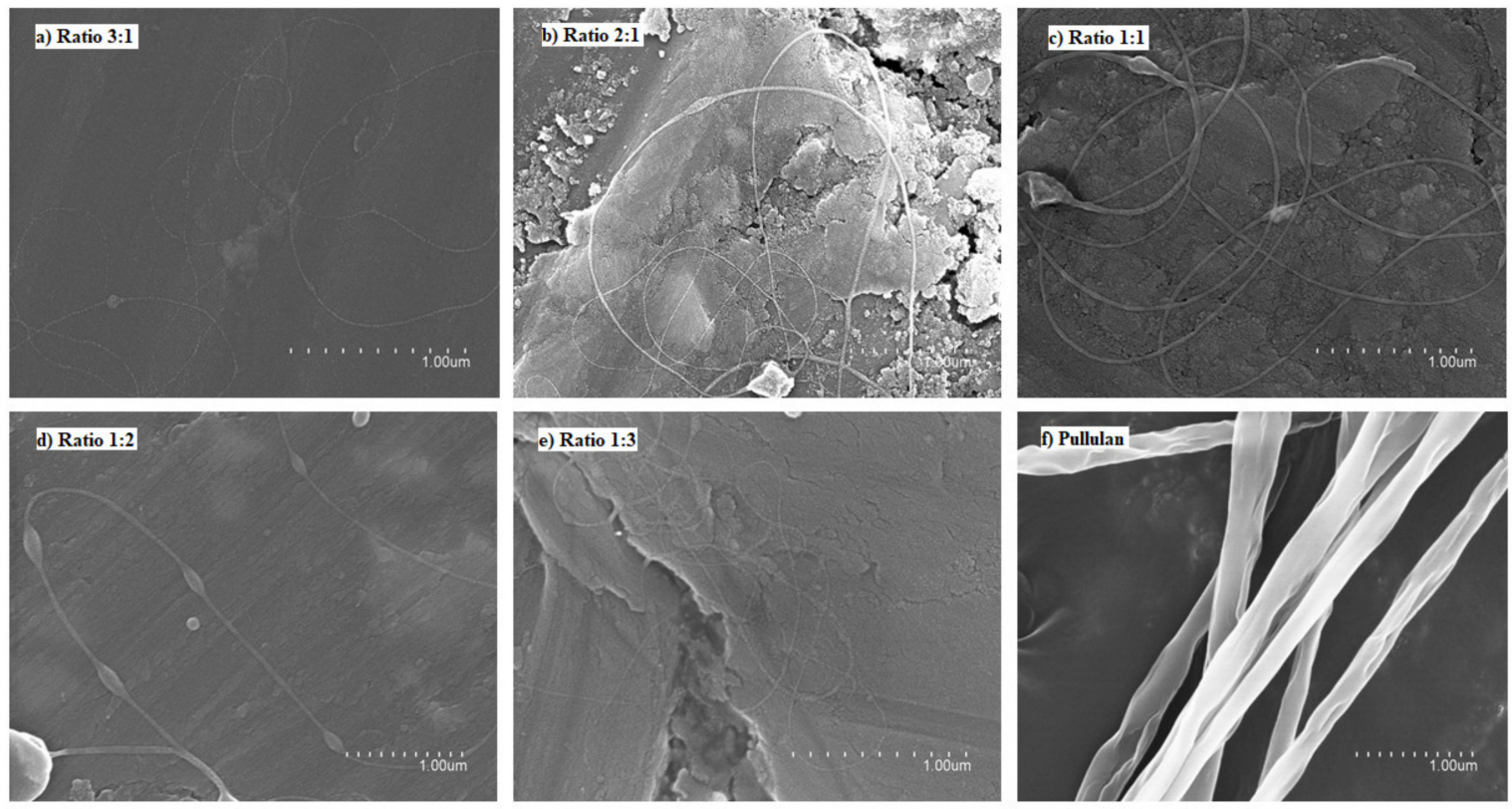

Figure 2. Scanning electron microscopy (SEM) images of the fibers obtained with the FucoPol:pullulan solutions. (a) 3:1 ratio, (b) 2:1 ratio, (c) 1:1 ratio, (d) 1:2 ratio, (e) 1:3 ratio, (f) 0:1 ratio (100\% pullulan).

On the other hand, pullulan showed uniform and cylindrical fibers with a rough surface, which could be caused by a combination of viscosity of the solution and the ambient conditions. This type of fiber is characteristic of pullulan due to the composition of the polymer. Pullulan has a single bond of maltotriose units interconnected by glycosidic bonds $\alpha(1,4)$ and $\alpha(1,6)$. This structure provides adhesive properties, as well as the ability to form fibers, compression molds and strong oxygen-impermeable films [2].

The studied ratios, shown in Figure 2, did not show significant differences, since the obtained fibers showed similar morphology and nanometric size. Although the different ratios of FucoPol:pullulan showed beads, these fibers were better than the fibers obtained with only FucoPol. FucoPol:pullulan nanofibers with a mass ratio of 2:1 $(w / w)$ were selected to continue the study. These fibers were obtained at a constant flow rate of $250 \mu \mathrm{L} / \mathrm{h}$, voltages of $23 \mathrm{kV}$ in the injector and $-2 \mathrm{kV}$ in the collector and distance between needle and collector of $28 \mathrm{~cm}$. 
Figure 3 shows the micrographs of the different solutions of FucoPol:PEO. Ratios of 3:1 and 1:2 (Figure 3a,d, respectively) showed fibers with a well-defined cylindrical structure and no beads. However, when samples were collected for a long time, fibers and particles were observed, similarly to the fibers obtained with FucoPol:pullulan solutions. Ratios of 2:1 and 1:1 did not show a stable process (Figure $3 b$ and Figure $3 c$, respectively). Fiber branching observed in Figure $3 c$, $f$ was due to the high voltage required to electrospin these solutions, which provoked an excess of surface charge on the jet, which was dissipated by branching [35]. However, a ratio of 1:3 led to thick, smooth, continuous and homogeneous fibers due to the higher amount of PEO (Figures 3e and 4). Even if some defects could be detected in Figure 4, they were much less numerous in comparison to the thicker films obtained with the other samples. The solution of FucoPol with PEO (1:3 ratio w/w) showed nanofibers with an average diameter of $0.587 \pm 0.200 \mu \mathrm{m}$. Those fibers were obtained at a constant flow rate of $300 \mu \mathrm{L} / \mathrm{h}$, with voltages of $22 \mathrm{kV}$ in the injector and $-2 \mathrm{kV}$ in the collector and a distance between the needle and the collector of $28 \mathrm{~cm}$. PEO is considered an electrospinnable polymer [29], since it improves the structural stability and the chargecarrying capacity of the solution, which is crucial for fiber formation [36]. This result is in agreement with previous studies that showed that the higher viscosity of the solution increases the diameter of fibers [15].
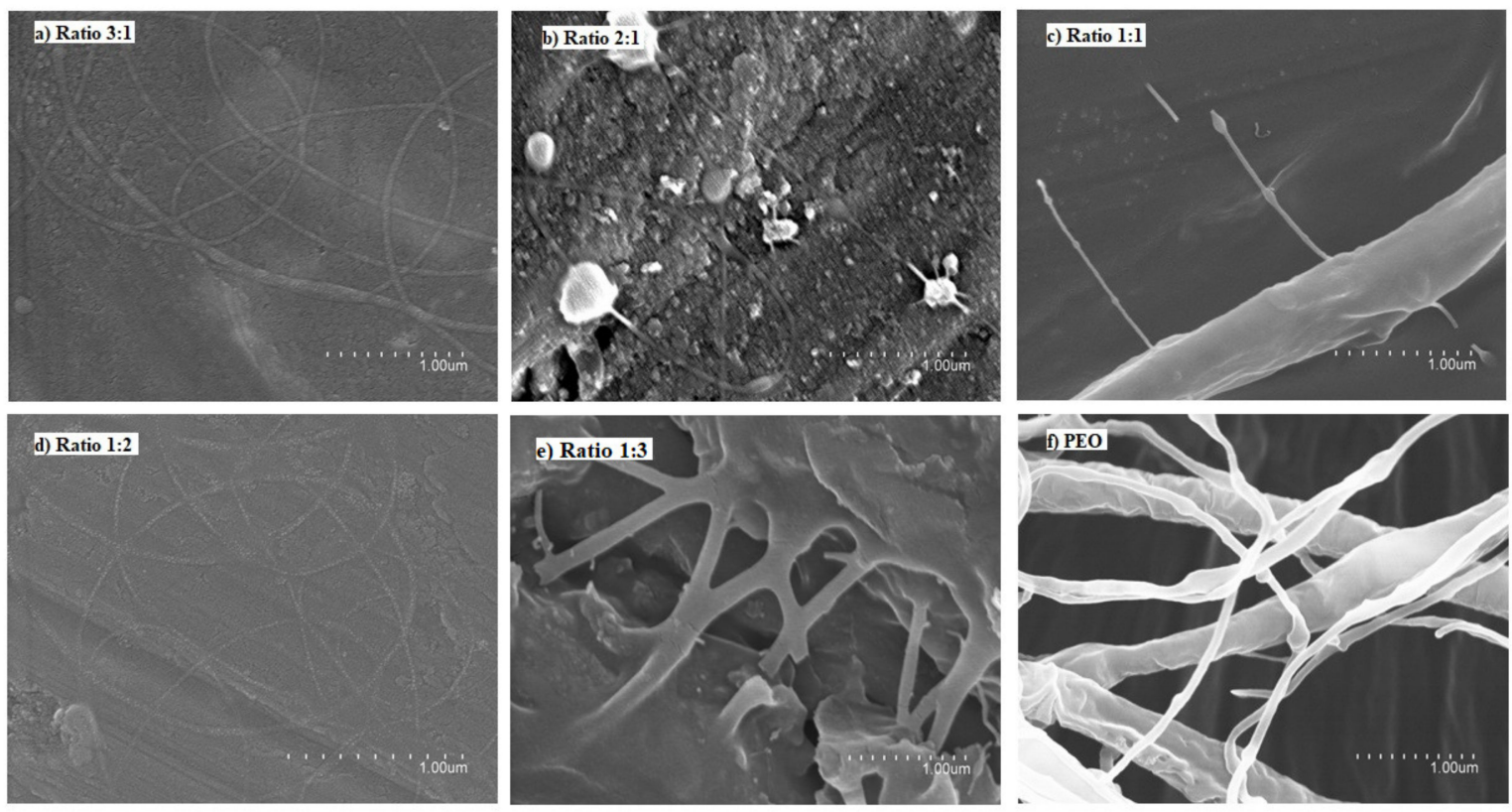

Figure 3. Scanning electron microscopy (SEM) images of the fibers obtained with the FucoPol:PEO solutions. (a) 3:1 ratio, (b) 2:1 ratio, (c) 1:1 ratio, (d) 1:2 ratio, (e) 1:3 ratio, (f) 0:1 ratio (100\% PEO).
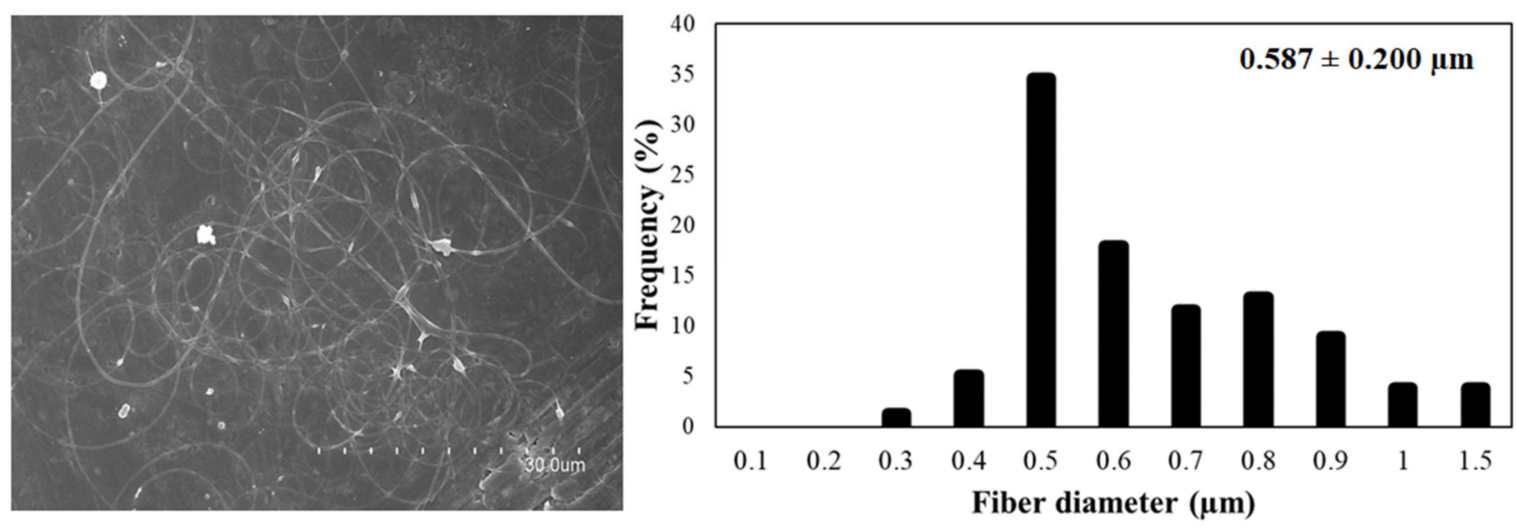

Figure 4. FucoPol:PEO fibers (1:3 ratio, $w / w)$ (left) and the average diameter of fibers (right). 


\subsection{Thermal Properties}

\subsubsection{Thermal Gravimetric Analysis (TGA)}

Thermogravimetric curves of FucoPol, FucoPol:pullulan (ratio 2:1, w/w) and FucoPol:PEO (ratio 1:3, w/w), along with TGA curves of pure polymers, which served as references, are shown in Figure 5. FucoPol showed three weight-loss steps (Figure 5f). The first step occurred between 25 and $109{ }^{\circ} \mathrm{C}$, referring to $13 \%$ of weight loss, which could be attributed to water evaporation [8,9]. The second step occurred between 220 and $364{ }^{\circ} \mathrm{C}$, referring to $52 \%$ of weight, and the third step occurred between 364 and $410{ }^{\circ} \mathrm{C}$, referring to $23 \%$ of weight loss. These two steps were attributed to biopolymer thermal degradation [8,37], specifically to decomposition of the polysaccharides side chains [9]. After these three steps, we observed a gradual weight loss, around $10 \%$ of total mass. It is important to note that after the electrospinning process, FucoPol showed only two weight-loss steps (Figure 5e), starting from $25-109^{\circ} \mathrm{C}$, corresponding to $4 \%$ of weight loss, attributed to the evaporation of water. The second step started from $140-378^{\circ} \mathrm{C}$, referring to $85 \%$ of weight loss, and after this, a gradual weight loss. This behavior is thought to be caused by the reduced size of the fibers and the presence of 3\% Span 20. The oily and hydrophobic nature [38] of Span 20 leads to a wide range of decomposition temperatures compared to pure FucoPol.
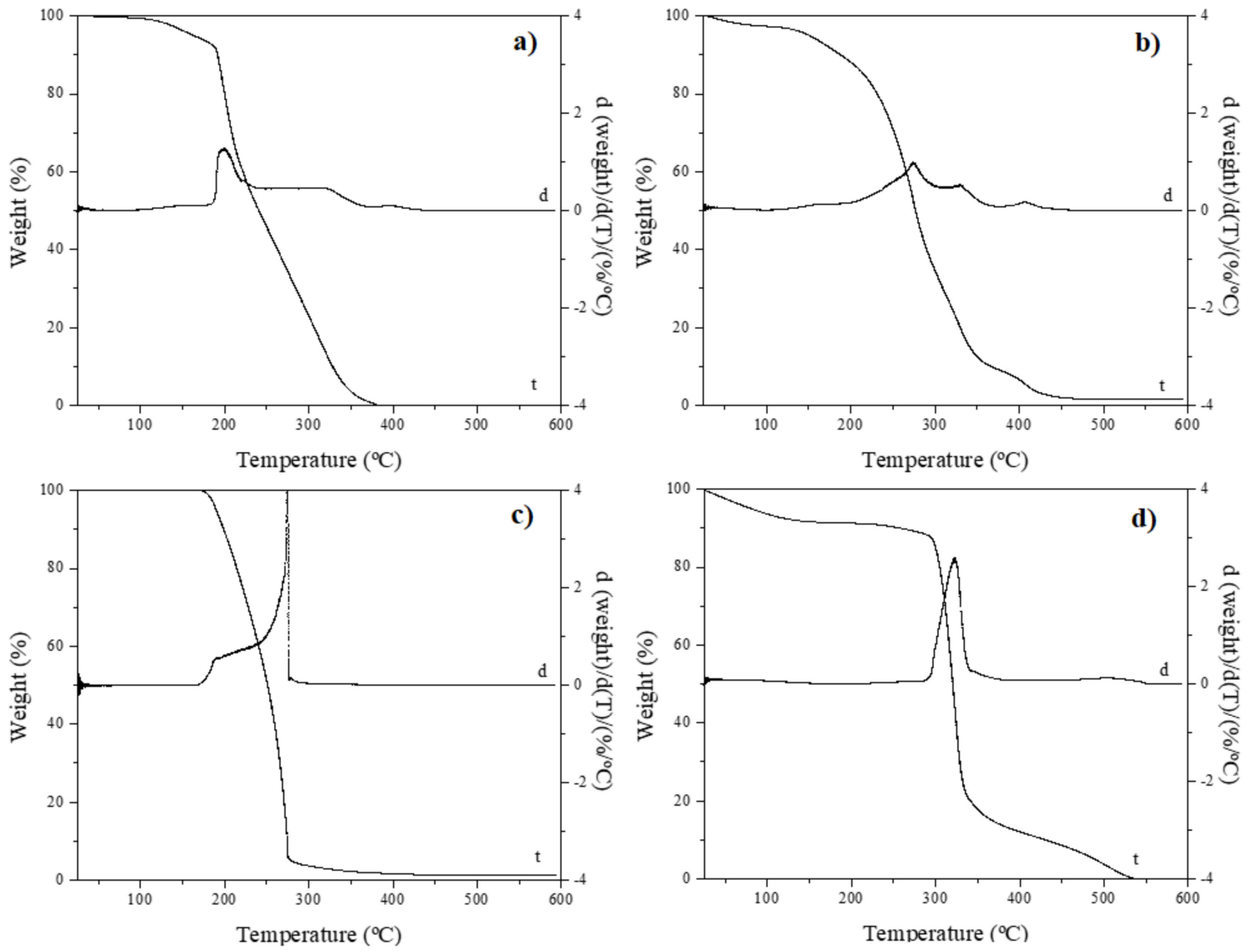

Figure 5. Cont. 

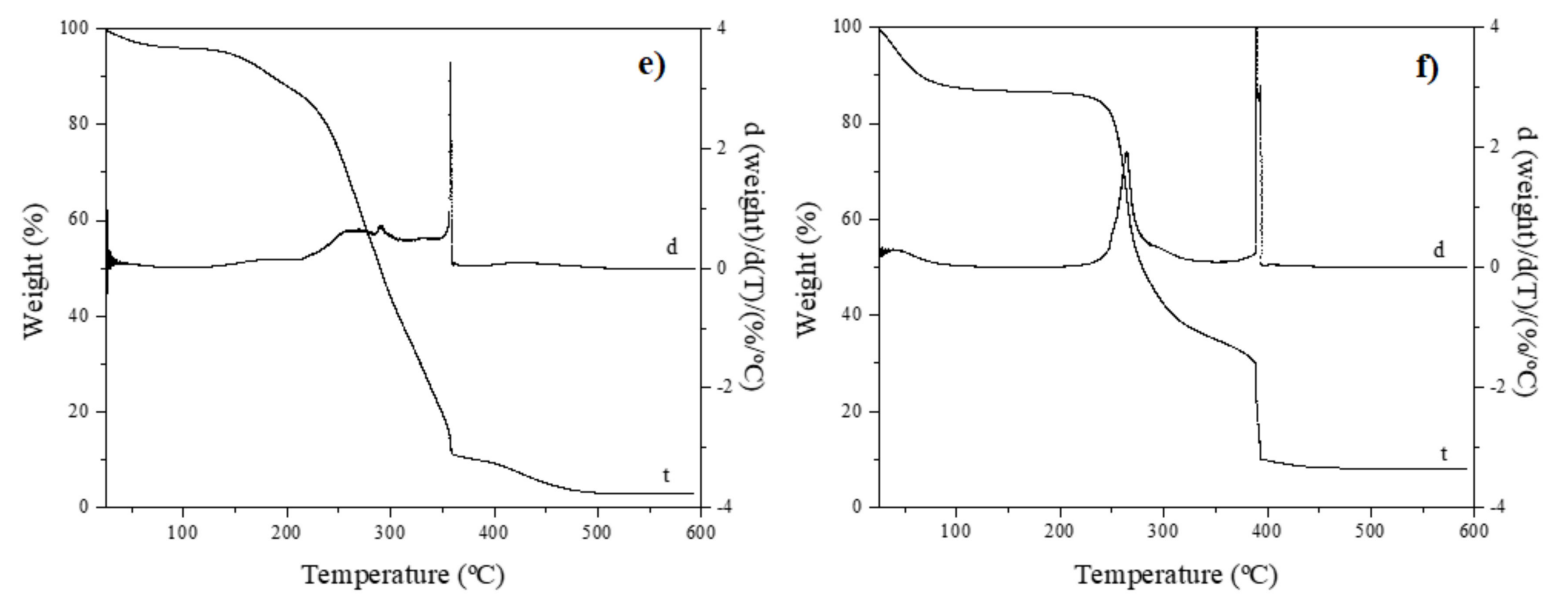

Figure 5. Thermogravimetric analysis of (a) FucoPol: PEO fibers, (b) FucoPol:pullulan fibers, (c) pure PEO, (d) pure pullulan, (e) FucoPol after electrospinning (mixture of fibers and particles) and (f) pure FucoPol. Curve $t$ represents thermogram, and $d$ is the thermogram derivate.

When it comes to FucoPol:PEO fibers, a similar thermal-degradation curve as for pure PEO is observed (Figure 5c). The thermal decomposition of PEO and FucoPol:PEO fibers consisted of only one weight-loss step. PEO showed $96 \%$ of weight loss between 160 and $301{ }^{\circ} \mathrm{C}$, while FucoPol:PEO fibers (Figure 5a) showed a step between 143 and $379{ }^{\circ} \mathrm{C}$ with a similar weight loss $(97 \%)$. The presence of PEO decreased the thermal stability of the fibers in comparison to pure FucoPol nanofibers.

Pullulan showed one important weight-loss step from 267 to $362^{\circ} \mathrm{C}$, corresponding to $74 \%$ of total weight loss (Figure $5 \mathrm{~d}$ ). Nevertheless, FucoPol:pullulan fibers showed a comparable thermal behavior to that of FucoPol after electrospinning (Figure 5e), attributed to the largest amount of FucoPol among the FucoPol:pullulan fibers $(2: 1 w / w)$. Weight loss started from 128 to $369{ }^{\circ} \mathrm{C}$, corresponding to $87 \%$ of total weight loss. This study confirms that the obtained nanofibers could be used in multiple applications in which the temperature does not exceed $120^{\circ} \mathrm{C}$. However, this temperature is enough to be subjected to several thermal processes, such as sterilization, as well as to non-thermal technologies, such as electrohydrodynamic processing, which opens a wide range of potential applications, such as pharmaceutics, biomedicine, biosensors, food packaging, agriculture, food or cosmetics, among others.

\subsubsection{Differential Scanning Calorimetry (DSC)}

DSC curves of fibers are illustrated in Figure 6. The DSC curve of pure FucoPol during the first run showed an endothermic peak at $85{ }^{\circ} \mathrm{C}, \Delta \mathrm{H} 113 \mathrm{~J} / \mathrm{g}$ (Figure $6 \mathrm{a}$ ), which was also observed by Lourenço et al. [8]. This may be attributed to the evaporation of sorbed water. During the second heating run, stopping at a higher temperature than in the first run, an exothermic peak at $279^{\circ} \mathrm{C}, \Delta \mathrm{H}-144 \mathrm{~J} / \mathrm{g}$ (Figure $6 \mathrm{c}$ ), was observed, which was attributed to polymer degradation. Additionally, Lourenço et al. reported an exothermic peak at around $270{ }^{\circ} \mathrm{C}$ [8]. Unambiguous melting or crystallization events were not discerned in the different heating and cooling ramps, suggesting an amorphous nature of the biopolymer. The same behavior was observed by Guerreiro et al. [39].

In the same way, pullulan showed a similar first-heating thermogram, with a broad peak between 44 and $166{ }^{\circ} \mathrm{C}$ instead of a sharp melting point (Figure 6a). This endotherm is also ascribed to moisture evaporation. The same behavior was observed by Singh et al. [40]. 


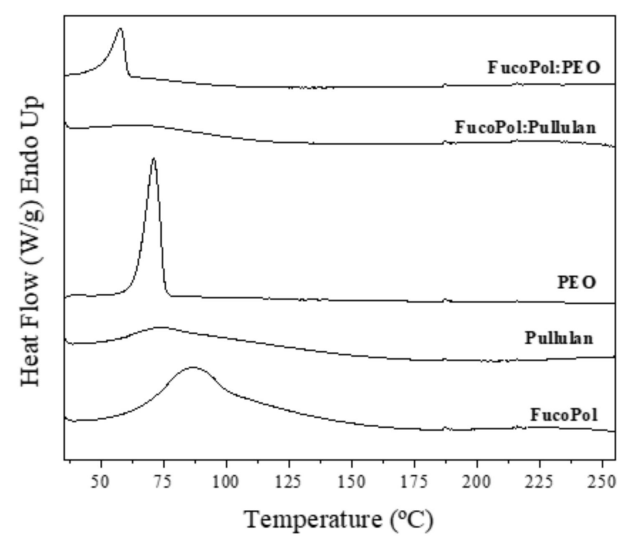

(a)

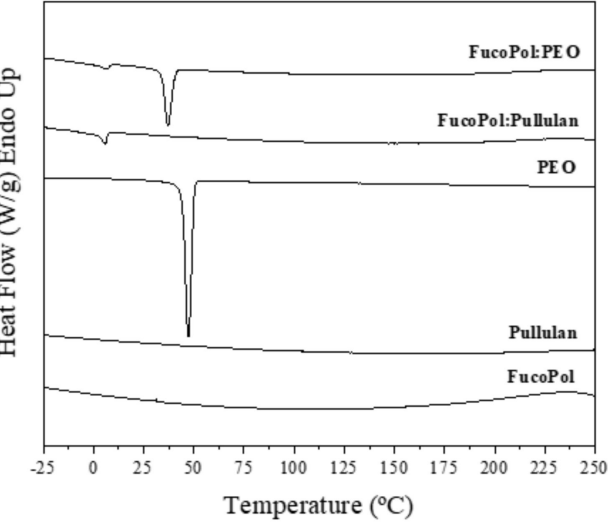

(b)

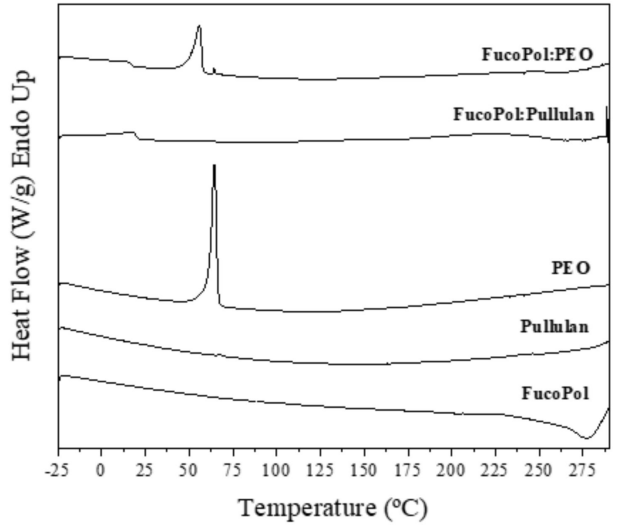

(c)

Figure 6. Differential scanning calorimetry curves of electrospun fibers and commercial polymers during (a) first heating, (b) cooling, and (c) second heating.

On the other hand, PEO is a semicrystalline polymer [41]. Figure 6a exhibits the melting temperature of PEO at $69^{\circ} \mathrm{C}, \Delta \mathrm{H} 151 \mathrm{~J} / \mathrm{g}$. Crystallization temperature was $47^{\circ} \mathrm{C}$, $\Delta \mathrm{H} 122 \mathrm{~J} / \mathrm{g}$ (Figure 6b). Similar results were reported by Balik et al. [42]. The FucoPol:PEO fibers showed similar behavior to that of pure PEO because PEO was the dominant polymer in the solution (1:3 ratio, $w / w$, Table 1$)$. However, melting and crystallization temperatures and enthalpies corrected for PEO content were reduced, i.e., $58^{\circ} \mathrm{C}, \Delta \mathrm{H} 76 \mathrm{~J} / \mathrm{g}$ and $37^{\circ} \mathrm{C}, \Delta \mathrm{H}$ $63 \mathrm{~J} / \mathrm{g}$, respectively, as shown in Figures $6 \mathrm{a}$ and $6 \mathrm{~b}$. This behavior was attributed to FucoPol impairing the crystallization of the PEO polymer in the blend. Guerreiro et al. [39] reported the formation of dispersed ice crystals in the presence of FucoPol when they studied the cryoprotective properties of FucoPol in water solutions. These authors observed that FucoPol significantly reduced the average size of the formed crystals.

Interestingly, during the crystallization and melting runs of the blends, small exothermic and endothermic events were seen at 10.5 and $17.5^{\circ} \mathrm{C}$, respectively, for FucoPol:pullulan and at 8.1 and $15.5^{\circ} \mathrm{C}$, respectively, for FucoPol:PEO, which may be ascribed to higher hierarchical molecular assemblies induced by blending (see WAXS results below).

\subsection{Wide-Angle X-ray Scattering (WAXS)}

WAXS allows for the characterization and quantification of the crystallinity present in a given sample through the diffraction patterns measured at wide angles [43]. Results of this analysis are shown in Figure 7. In this context, pure FucoPol and pullulan showed no sharp peaks in the $2 \theta$ range, suggesting again a rather amorphous nature [8,44-48]. On the other hand, pure PEO showed a clear crystalline phase with two intense peaks at $19^{\circ}$ and at $23^{\circ}$ (Figure 7 ). These observations are consistent with the results obtained by other authors, who reported two characteristic diffraction peaks at $2 \theta=19^{\circ}$ and $23.5^{\circ}$ for crystalline PEO [49] and weak crystalline peaks at around $15^{\circ}, 26^{\circ}$ and $36^{\circ}$ [50,51]. 
These peaks are attributed to the well reported ordered $7 / 2$ helical structure of PEO, i.e., seven ethylene oxide repeat units with two turns in a fiber period of $1.93 \mathrm{~nm}$ [51]. In the FucoPol:PEO fibers, the crystalline patterns of PEO are weaker than in the pure polymer but can be clearly discerned. In addition, some new peaks were detected in both blends at angles below $10^{\circ}$. In the case of FucoPol:PEO fibers, they exhibited a new tiny peak at $7^{\circ}$, which suggests that PEO could affect the FucoPol biopolymer hierarchical assembly. Additionally, both blends show a stronger peak at around $3^{\circ}$. Peaks at these low angles have been attributed to helical secondary structures, as well as other higher hierarchical assemblies by other authors [52-54].

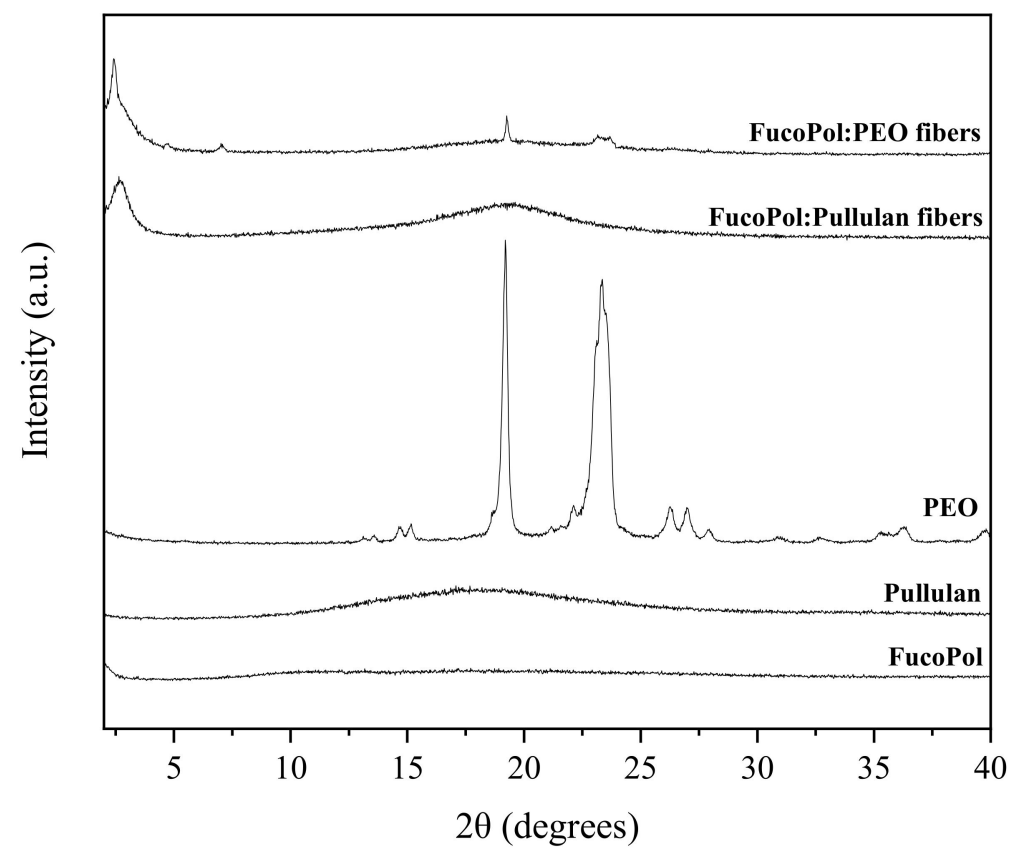

Figure 7. WAXS profiles of fibers of FucoPol with PEO and pullulan, respectively, as well as pure polymers.

\subsection{Attenuated Total Reflectance-Fourier Transform Infrared Spectroscopy (ATR-FTIR)}

The ATR-FTIR spectra of the fibers that contain FucoPol are presented in Figure 8, along with the spectra of complementary polymers pullulan and PEO for comparison. The broad intense band around $3400 \mathrm{~cm}^{-1}$ is common for all samples containing polysaccharides (Figure $8 \mathrm{a}, \mathrm{b}, \mathrm{d}, \mathrm{e}, \mathrm{g}$ ). This band represents $\mathrm{O}-\mathrm{H}$ stretching of hydroxyls and bound water [55]. This band overlaps in part with the $\mathrm{C}-\mathrm{H}$ stretching peak of $\mathrm{CH}_{2}$ groups appearing at $2940 \mathrm{~cm}^{-1}$ in the case of FucoPol and pullulan, as shown in Figures $8 \mathrm{~g}$ and 8d, respectively. FucoPol bands at 1200 and $900 \mathrm{~cm}^{-1}$ represent skeletal $\mathrm{C}-\mathrm{O}$ and $\mathrm{C}-\mathrm{C}$ vibration bands of glycosidic bonds and pyranoid rings [55]. The band at $1720 \mathrm{~cm}^{-1}$ is attributed to the $\mathrm{C}=\mathrm{O}$ stretching of carbonyls in acyl groups. The band at $1250 \mathrm{~cm}^{-1}$ may also be attributed to the $\mathrm{C}-\mathrm{O}-\mathrm{C}$ vibration of acyls and was explored by Freitas et al. [7]. In the same way, the strong bands at 1607 and $1405 \mathrm{~cm}^{-1}$, can be attributed to the asymmetric and symmetric stretchings, respectively, of carboxylates [55]. All peaks shown by FucoPol (Figure 8g) in this study match those reported by Freitas et al. [7] during the characterization of a fucose-containing exopolysaccharide produced by the newly isolated Enterobacter strain A47 DSM 23139. 


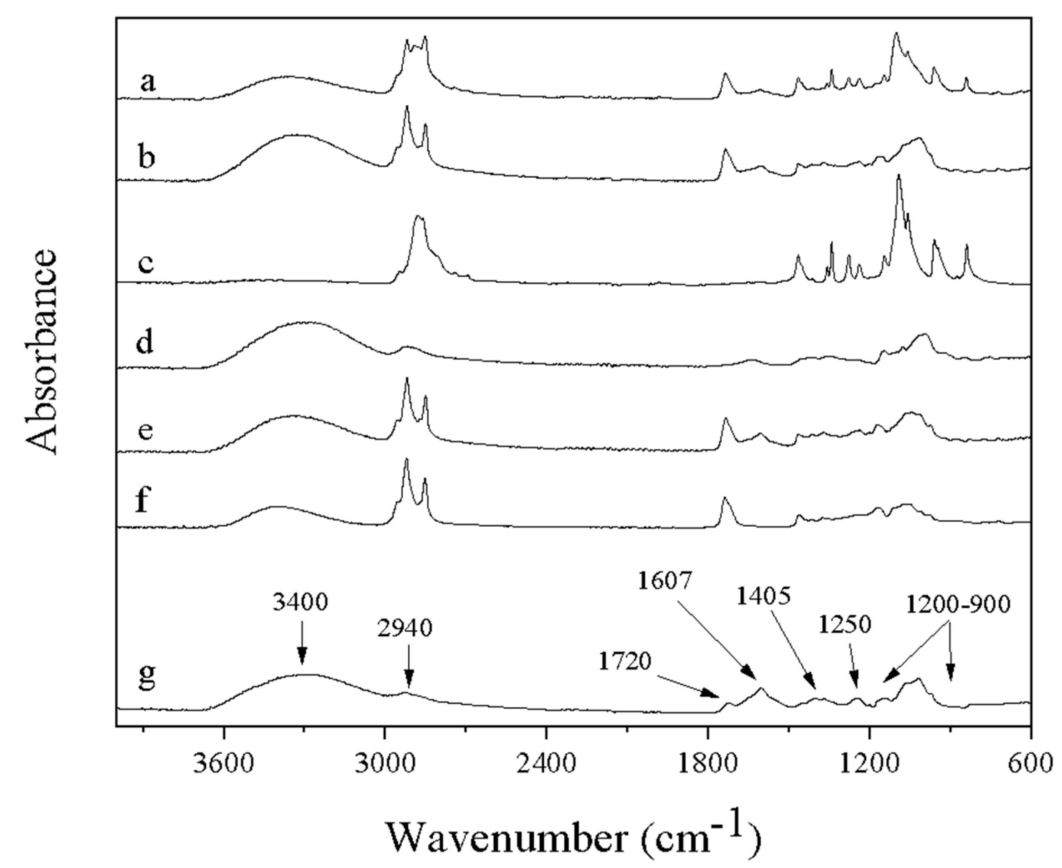

Figure 8. FTIR spectra of (a) FucoPol:PEO fibers, (b) FucoPol:pullulan fibers, (c) pure PEO, (d) pure pullulan, (e) FucoPol after electrospinning (mixture of fibers and particles), (f) Span 20 and (g) pure FucoPol.

The fibers of FucoPol:PEO and FucoPol:pullulan showed characteristic bands corresponding to the same bands of pure polymers PEO and pullulan, respectively (Figure $8 \mathrm{c}, \mathrm{d}$ ). In addition, the presence of the Span 20 was also observed, since new bands appeared in the spectrum of fibers at ca. 2920 and $2850 \mathrm{~cm}^{-1}$, attributed to $\mathrm{CH}_{2}$ and $\mathrm{CH}_{3}$ scissoring [56] of the lipids that form this surfactant, even in FucoPol after electrospinning. The absence of changes in the characteristic bands in the electrospun nanofibers with respect to the pure components proves the absence of chemical reactions and degradation during the applied treatment.

\section{Conclusions}

Electrospun FucoPol nanofibers were not able to be produced from water or alcohol solutions-only by blending with other polymers, such as PEO and pullulan. FucoPol was found to be an amorphous biopolymer stable until $220^{\circ} \mathrm{C}$, but it was not possible to obtain homogeneous nanofibers due to the low water solubility and lack of molecular entanglements. The blend of FucoPol:PEO showed non-agglomerated and homogeneous nanofibers with cylindrical morphology, as well as reduced crystallinity in comparison with pure PEO fibers when normalized for content, and was stable until $140{ }^{\circ} \mathrm{C}$. The blend of FucoPol:pullulan showed an amorphous nature and was stable until $130{ }^{\circ} \mathrm{C}$. Interestingly, the blending components influenced one another in the intermolecular order, since new peaks ascribed to intermolecular hierarchical assemblies were seen by WAXS for FucoPol. The well-known functional properties of FucoPol, together with the possibility to form stable electrospun fibers with controllable morphology and porosity, as well as the interesting structural and thermal properties shown in previous results, opens a new research line concerning the potential applications of FucoPol electrospun fibers in the food packaging, agricultural, biomedical, pharmaceutical, cosmetic and food industries, among others.

Author Contributions: Conceptualization by J.M.L.; methodology, validation, and formal analysis was carried out by Y.V.-G., M.S., C.P., C.A.V.T., F.F. and J.M.L.; investigation, resources, data curation, writing-original draft preparation, review and editing were performed by Y.V.-G., M.S., C.P., F.F., C.A.V.T., J.A.R.-S., M.C.-S. and J.M.L.; visualization, supervision, project administration and funding 
acquisition were carried out by C.P., M.C.-S. and J.M.L. All authors have read and agreed to the published version of the manuscript.

Funding: This study was supported by the CYTED thematic network (code 319RT0576), the Spanish Ministry of Science and Innovation (MICI) project RTI-2018-097249-B-C21 and H2020 EU project USABLE PACKAGING (reference number 836884). This work received financial support from FCTFundação para a Ciência e a Tecnologia, I.P. (Portugal), in the scope of projects UIDP/04378/2020 and UIDB/04378/2020 of the Research Unit on Applied Molecular Biosciences-UCIBIO, and project LA/P/0140/2020 of the Associate Laboratory Institute for Health and Bioeconomy-i4HB.

Data Availability Statement: No application.

Acknowledgments: Yuliana Vázquez González thanks Consejo Nacional de Ciencia y Tecnología for the fellowship awarded with number 754518. Milan Stojanovic acknowledges the European Institute of Innovation \& Technology (EIT) for the fellowship EIT Food KAVA \#20272/2020.

Conflicts of Interest: The authors declare no conflict of interest.

\section{References}

1. Daba, G.M.; Elnahas, M.O.; Elkhateeb, W.A. International Journal of Biological Macromolecules Contributions of exopolysaccharides from lactic acid bacteria as biotechnological tools in food, pharmaceutical, and medical applications. Int. J. Biol. Macromol. 2021, 173, 79-89. [CrossRef] [PubMed]

2. Singh, R.S.; Saini, G.K.; Kennedy, J.F. Pullulan: Microbial sources, production and applications. Carbohydr. Polym. 2008, 73, 515-531. [CrossRef] [PubMed]

3. Torres, C.A.V.; Marques, R.; Antunes, S.; Alves, V.D.; Sousa, I.; Maria, A.; Oliveira, R.; Freitas, F.; Reis, M.A.M. Kinetics of production and characterization of the fucose-containing exopolysaccharide from Enterobacter A47. J. Biotechnol. 2011, 156, 261-267. [CrossRef] [PubMed]

4. Dsm, A.; Freitas, F.; Alves, V.D.; Torres, C.A.V.; Cruz, M.; Sousa, I.; João, M.; Ramos, A.M.; Reis, M.A.M. Fucose-containing exopolysaccharide produced by the newly isolated. Carbohydr. Polym. 2011, 83, 159-165. [CrossRef]

5. Freitas, F.; Alves, V.D.; Gouveia, A.R.; Grandfils, C.; Reis, M.A.M. Controlled Production of Exopolysaccharides from Enterobacter A47 as a Function of Carbon Source with Demonstration of Their Film and Emulsifying Abilities. Appl. Biochem. Biotechnol. 2014, 172, 641-657. [CrossRef]

6. Araújo, D.; Alves, V.D.; Campos, J.; Coelhoso, I.; Sevrin, C.; Grandfils, C.; Freitas, F.; Reis, M.A.M. International Journal of Biological Macromolecules Assessment of the adhesive properties of the bacterial polysaccharide FucoPol. Int. J. Biol. Macromol. 2016, 92, 383-389. [CrossRef]

7. Freitas, F.; Alves, V.D.; Reis, M.A.M. Advances in bacterial exopolysaccharides: From production to biotechnological applications. Trends Biotechnol. 2011, 29, 388-398. [CrossRef]

8. Lourenc, S.C.; Torres, C.A.V.; Nunes, D.; Duarte, P.; Freitas, F.; Reis, M.A.M.; Fortunato, E.; Moldão-martins, M.; Beirão, L.; Alves, V.D. International Journal of Biological Macromolecules Using a bacterial fucose-rich polysaccharide as encapsulation material of bioactive compounds. Int. J. Biol. Macromol. 2017, 104, 1099-1106. [CrossRef]

9. Concórdio-reis, P.; Pereira, C.V.; Batista, M.P.; Sevrin, C.; Grand, C.; Marques, A.C.; Fortunato, E.; Gaspar, F.B.; Matias, A.A.; Freitas, F.; et al. International Journal of Biological Macromolecules Silver nanocomposites based on the bacterial fucose-rich polysaccharide secreted by Enterobacter A47 for wound dressing applications: Synthesis, characterization and in vitro bioactivity. Int. J. Biol. Macromol. 2020, 163, 959-969. [CrossRef]

10. Ferreira, A.R.V.; Torres, C.A.V.; Freitas, F.; Reis, M.A.M.; Vítor, D.; Coelhoso, I.M. International Journal of Biological Macromolecules Biodegradable films produced from the bacterial polysaccharide FucoPol. Int. J. Biol. Macromol. 2014, 71, 111-116. [CrossRef]

11. Ferreira, A.R.V.; Torres, C.A.V.; Freitas, F.; Sevrin, C.; Grandfils, C.; Reis, M.A.M.; Alves, V.D.; Coelhoso, I.M. Development and characterization of bilayer films of FucoPol and chitosan. Carbohydr. Polym. 2016, 147, 8-15. [CrossRef] [PubMed]

12. Ferreira, A.R.V.; Haapanen, J.; Mäkelä, J.M.; Bratvold, J.E.; Nilsen, O.; Tuominen, M.; Alves, V.D.; Coelhoso, I.M. International Journal of Biological Macromolecules Comparison of different coating techniques on the properties of FucoPol films. Int. J. Biol. Macromol. 2017, 103, 268-274. [CrossRef] [PubMed]

13. Ferreira, A.R.V.; Bandarra, N.M.; Moldão-martins, M.; Coelhoso, I.M.; Alves, V.D. FucoPol and chitosan bilayer fi lms for walnut kernels and oil preservation. LWT Food Sci. Technol. 2018, 91, 34-39. [CrossRef]

14. Bhardwaj, N.; Kundu, S.C. Electrospinning: A fascinating fi ber fabrication technique. Biotechnol. Adv. 2010, 28, 325-347. [CrossRef]

15. Marcela, L.; Sánchez, D.; Rodriguez, L.; López, M. Electrospinning: La era de las Nanofibras. Rev. Iberoam. Polímeros 2014, 14, 10-27.

16. Bhushani, J.A. Electrospinning and electrospraying techniques: Potential food based applications. Trends Food Sci. Technol. 2014, 38, 21-33. [CrossRef] 
17. Leidy, R.; Ximena, Q.M. Trends in Food Science \& Technology Use of electrospinning technique to produce nano fi bres for food industries: A perspective from regulations to characterisations. Trends Food Sci. Technol. 2019, 85, 92-106. [CrossRef]

18. Frenot, A.; Chronakis, I.S. Polymer nanofibers assembled by electrospinning. Curr. Opin. Colloid Interface Sci. 2003, 8, 64-75. [CrossRef]

19. Fong, H.; Chun, I.; Reneker, D.H. Beaded nanofibers formed during electrospinning. Polymer 1999, 40, 4585-4592. [CrossRef]

20. Torres-Giner, S.; Pérez-Masiá, R.; Lagaron, J.M. A review on electrospun polymer nanostructures as advanced bioactive platforms. Polym. Eng. Sci. 2016, 56, 500-527. [CrossRef]

21. Torres-giner, S.; Wilkanowicz, S.; Melendez-rodriguez, B.; Lagaron, J.M. Nanoencapsulation of Aloe vera in Synthetic and Naturally Occurring Polymers by Electrohydrodynamic Processing of Interest in Food Technology and Bioactive Packaging. J. Agric. Food Chem. 2017, 65, 4439-4448. [CrossRef] [PubMed]

22. Wang, S.; Yang, Y.; Zhang, Y.; Fei, X.; Zhou, C.; Zhang, Y.; Li, Y.; Yang, Q.; Song, Y. Fabrication of large-scale superhydrophobic composite films with enhanced tensile properties by multinozzle conveyor belt electrospinning. J. Appl. Polym. Sci. 2014, 131, 39735. [CrossRef]

23. Barhoum, A.; Rasouli, R.; Yousefzadeh, M. Nanofiber Technologies: History and Development. Handbook of Nanofibers; Springer International Publishing AG: Cham, Switzerland, 2019; ISBN 9783319536552.

24. Teck, C. Progress in Polymer Science Nanofiber technology: Current status and emerging developments. Prog. Polym. Sci. 2017, 70, 1-17.

25. Alves, V.D.; Freitas, F.; Torres, C.A.V.; Cruz, M.; Marques, R.; Grandfils, C.; Gonc, M.P.; Oliveira, R.; Reis, M.A.M. Rheological and morphological characterization of the culture broth during exopolysaccharide production by Enterobacter sp. Carbohydr. Polym. 2010, 81, 758-764. [CrossRef]

26. Hilliou, L.; Freitas, F.; Oliveira, R.; Reis, M.A.M.; Lespineux, D.; Grandfils, C.; Alves, V.D. Solution properties of an exopolysaccharide from a Pseudomonas strain obtained using glycerol as sole carbon source. Carbohydr. Polym. 2009, 78, 526-532. [CrossRef]

27. Lidón, E.; Safont, S.; Aldureid, A.; María, J.; Jose, L.; Perez, G.; Cabedo, L. Effect of the Purification Treatment on the Valorization of Natural Cellulosic Residues as Fillers in PHB-Based Composites for Short Shelf Life Applications. Waste Biomass Valorization 2021, 12, 2541-2556. [CrossRef]

28. Deitzel, J.M.; Kleinmeyer, J.; Harris, D.; Tan, N.C.B. The effect of processing variables on the morphology of electrospun nanofibers and textiles. Polymer 2001, 42, 261-272. [CrossRef]

29. Vidinha, R.; Botequim, D.; Borges, J.P. A systematic study of solution and processing parameters on nanofiber morphology using a new electrospinning apparatus A Systematic Study of Solution and Processing Parameters on Nanofiber Morphology Using a New Electrospinning Apparatus. J. Nanosci. Nanotechnol. 2009, 9, 3535-3545. [CrossRef]

30. Li, S.; Xia, H.; Xie, A.; Wang, Z.; Ling, K.; Zhang, Q.; Zou, X. International Journal of Biological Macromolecules Structure of a fucose-rich polysaccharide derived from EPS produced by Kosakonia sp. CCTCC M2018092 and its application in antibacterial film. Int. J. Biol. Macromol. 2020, 159, 295-303. [CrossRef]

31. Jaworek, A. Electrospray droplet sources for thin film deposition. J. Mater. Sci. 2007, 42, 266-297. [CrossRef]

32. Hayati, I.; Bailey, A.I.; Tadros, T.H.F. Investigations into the Mechanisms of Electrohydrodynamic Spraying of Liquids I. Effect of Electric Field and the Environment on Pendant Drops and Factors Affecting the Formation of Stable Jets and Atomization. J. Colloid Interface Sci. 1987, 117, 205-221. [CrossRef]

33. Shenoy, S.L.; Bates, W.D.; Frisch, H.L.; Wnek, G.E. Role of chain entanglements on fiber formation during electrospinning of polymer solutions: Good solvent, non-specific polymer-Polymer interaction limit. Polymer 2005, 46, 3372-3384. [CrossRef]

34. Yu, J.; Qiu, Y.; Zha, X.; Yu, M.; Yu, J.; Rafique, J.; Yin, J. Production of aligned helical polymer nanofibers by electrospinning. Eur. Polym. J. 2008, 44, 2838-2844. [CrossRef]

35. Ti, P. Branching effect and morphology control in electrospun. J. Mater. Res. 2014, 29, 1721-1729. [CrossRef]

36. Francis, L.; Balakrishnan, A.; Sanosh, K.P.; Marsano, E. Characterization and tensile strength of HPC-PEO composite fi bers produced by electrospinning. Mater. Lett. 2010, 64, 1806-1808. [CrossRef]

37. Vendruscolo, C.W.; Ferrero, C.; Pineda, E.A.G.; Silveira, J.L.M.; Freitas, R.A.; Jiménez-castellanos, M.R.; Bresolin, T.M.B. Physicochemical and mechanical characterization of galactomannan from Mimosa scabrella: Effect of drying method. Carbohydr. Polym. 2009, 76, 86-93. [CrossRef]

38. Geng, Q.; Chen, J.; Guo, R.; Zhang, L.; Li, Q.; Yu, X. Salt-assisted aqueous extraction combined with Span 20 allow the obtaining of a high-quality and yield walnut oil. LWT 2020, 121, 108956. [CrossRef]

39. Guerreiro, B.M.; Freitas, F.; Lima, J.C.; Silva, J.C.; Dionísio, M.; Reis, M.A.M. Demonstration of the cryoprotective properties of the fucose-containing polysaccharide FucoPol. Carbohydr. Polym. 2020, 245, 116500. [CrossRef]

40. Sarup, R.; Kaur, N.; Pandey, A.; Kennedy, J.F. Bioresource Technology Reports Hyper-production of pullulan from de-oiled rice bran by Aureobasidium pullulans in a stirred tank reactor and its characterization. Bioresour. Technol. Rep. 2020, 11, 100494. [CrossRef]

41. Lu, C.; Wai, S.; Du, H.; Li, J.; Gan, L.; Zhang, X.; Chu, X.; Yao, Y.; Li, B.; Kang, F. Thermal conductivity of electrospinning chain-aligned polyethylene oxide (PEO). Polymer 2017, 115, 52-59. [CrossRef]

42. Balik, B.A.; Argin, S.; Lagaron, J.M. Preparation and Characterization of Electrospun Pectin-Based Films and Their Application in Sustainable Aroma Barrier Multilayer Packaging. Appl. Sci. 2019, 9, 5136. [CrossRef] 
43. Louati, M.; Tahon, J.; Fournier, D.; Stoclet, G.; Takao, M.; Takeshita, M.; Lefebvre, J.; Barrau, S. In-situ SAXS/WAXS investigations of ureidopyrimidinone functionalized semi-crystalline poly (ethylene-co-butylene) supramolecular polymers. Polymer 2021, 228, 123875. [CrossRef]

44. Haghighatpanah, N.; Mirzaee, H.; Khodaiyan, F.; Kennedy, J.F.; Aghakhani, A.; Saeid, S.; Jahanbin, K. Optimization and characterization of pullulan produced by a newly identi fi ed strain of Aureobasidium pullulans. Int. J. Biol. Macromol. 2020, 152, 305-313. [CrossRef] [PubMed]

45. Mao, Y.; Su, Y.; Hsiao, B.S. Probing structure and orientation in polymers using synchrotron small- and wide-angle X-ray scattering techniques. Eur. Polym. J. 2016, 81, 433-446. [CrossRef]

46. Sarup, R.; Kaur, N.; Sharma, R.; Rana, V. International Journal of Biological Macromolecules Carbamoylethyl pullulan: QbD based synthesis, characterization and corneal wound healing potential. Int. J. Biol. Macromol. 2018, 118, 2245-2255. [CrossRef]

47. Trovatti, E.; Fernandes, S.C.M.; Rubatat, L.; Perez, S.; Freire, C.S.R.; Silvestre, A.J.D.; Pascoal, C. Pullulan-Nanofibrillated cellulose composite films with improved thermal and mechanical properties. Compos. Sci. Technol. 2012, 72, 1556-1561. [CrossRef]

48. van Drongelen, M.; Meijer-vissers, T.; Cavallo, D.; Portale, G.; Vanden, G.; Androsch, R. Thermochimica Acta Microfocus wide-angle X-ray scattering of polymers crystallized in a fast scanning chip calorimeter. Thermochim. Acta 2013, 563, 33-37. [CrossRef]

49. Liu, R.; Jin, L.; Lu, D.; Hu, G.; He, L.; Shan, J. Electrochimica Acta Bi-continuous phases structured nanocomposite polymer electrolytes: Facile preparation and electrochemical properties. Electrochim. Acta 2013, 114, 372-378. [CrossRef]

50. Lin, H.; Kai, T.; Freeman, B.D.; Kalakkunnath, S.; Kalika, D.S. The Effect of Cross-Linking on Gas Permeability in Cross-Linked Poly (Ethylene Glycol Diacrylate). Macromolecules 2005, 38, 8381-8393. [CrossRef]

51. Sunderrajan, S.; Freeman, B.D.; Hall, C.K.; Pinnau, I. Propane and propylene sorption in solid polymer electrolytes based on poly (ethylene oxide) and silver salts. J. Membr. Sci. 2001, 182, 1-12. [CrossRef]

52. Michael, D. Structural Hierarchy in Linear Polysaccharides-From the Nano- to Macroscale. Ph.D. Thesis, ETH Zurich, Zurich, Switzerland, 2020.

53. Fittolani, G.; Seeberger, P.H.; Delbianco, M. Helical polysaccharides. Peptide Sci. 2020, 112, e24124. [CrossRef]

54. Khan, M.A.; Zhou, C.; Zheng, P.; Zhao, M.; Liang, L. Improving Physicochemical Stability of Quercetin-Loaded Hollow Zein Particles with Chitosan/Pectin Complex Coating. Antioxidants 2021, 10, 1476. [CrossRef] [PubMed]

55. Mate, P.; Machovic, V.; Synytsya, A. Fourier transform Raman and infrared spectroscopy of pectins. Carbohydr. Polym. 2003, 54, 97-106. [CrossRef]

56. Ali, A.; Talpur, F.N.; Aqeel, M.; Cebeci, A.; Jawaid, S.; Imran, H. Monitoring the Rhizopus oryzae lipase catalyzed hydrolysis of castor oil by ATR-FTIR spectroscopy. J. Mol. Catal. B Enzym. 2015, 113, 56-61. [CrossRef] 